\title{
EVLİlì́K DIŞINDA DOĞAN ÇOCUKLARIN TANINMASI ALANINDA KANUNLAR ÇATIŞMASI
}

\author{
(Türk - Alman Olaylari)
}

Prof. Dr. Tuğñl ANSAY

\section{GIRIŞ :}

Almanya'da çalışan Türklerin ortaya çıkardı̆̆ı sorunlardan bir tanesi bu Türk vatandaşlamndan evlilik dişında doğan çocuklarin hukuki durumudur. Türk erkeğin Türkiye'de esasen evli bulunması, tanıma veya babalığa hüküm yoluyla çocukların neseplerinin düizeltilmesini engellediğinden hukuki durum daha da karışık bir hal alabilmektedir. ${ }^{1}$ Türk erkeklerinden evlilik dıșı doğan çocukların büyük bir kısmında ananın Alman tabiiyetinde oldugu anlaşılmakta. dır. Fakat Türk veya diğer yabancı kadınlarla ilişkilerden doğan evlilik đışı çocukların da sayısını azımsamamak gerekir. Özellikle Yugoslavya ve Yunanistandan Türk asıllı işçilerin de Almanya'ya geldiği bir gerçektir.

Almanya ile ilgili istatistiklere göre, bu ïlkede her 1.000 doğumda evlilik dışı doğan çocuklann sayısı șöyledir ${ }^{2}$ :

1965

1969

1970
46,9

50.4

54,6 (kesin olmayan rakkam).

'Almanyada çalıșan 2.3 milyon iş̧̧inin 722.000 'i evlidir. Evli olanların \% 40'1 ailelerinden ayr yaşamaktadırlar. Frankfurter Alıgemeine Zeitung, 17.10. 1972. S. 7, Nr. 241.

- Kaynak : Statistisches Jahrbuch für die BRD, 1971, S. 45.

Hamburg Konsolosluy̆gumuzdan edindiğimiz bilgiye göre, yılda ortalama 50-60 arasında evlilik dıșı çocuk olayı bu Konsolosluğa gelmektedir. Hamburg Konsolosluğı bölgesinde (Schleswig - Holstein'i de içine almaktadır) yaklaşık olarak 30.000 Türk yașamaktadır. (27.241 Türk iş̧̧i, Die Welt, 8.11.1972, S. 21) 1970 yılında bu bölgedeki Türk işçi sayısı 18.000 idi. Bunun yaklaşık olarak \% 25'i kadun olduğuna göre, aynı bölgede yașyan 
Babalığın tespiti ile ilgili rakkamlar ise șöyledir ${ }^{3}$ :

$\begin{array}{ll}1967 & 51.480 \\ 1968 & 51.158 \\ 1969 & 49.051\end{array}$

Bu rakkamlar gerçi evlilik dışı doğan çocuklamn ne kadarının yabancı erkek veya kadınlara ait olduğunu ve babalık tespitinde babanın hangi tabiiyette bulunduğunu göstermemektedir. Fakat yabancı erkeklerden ve bu arada Türk iş̧̧ilerinden evlilik dışında doğan çocukların sayllarının yüksek olduğu tahmin edilebilir. Toplayabildiğimiz Alman mahkeme kararlarından Türklerle ilgili olanlanını pek çoğu ve Alman bilirkiși raporlarının büyük bir kısmı - tanıma bir dava konusu olmadığı halde- evlilik dıșında doğan çocuklara dairdir. ${ }^{4}$

Evlilik dışında doğan çocukların tabiî babalarn ile aralarında. ki nesep iliş̧kisi çeșitli yollarla kurulabilir. Bazı hallerde çocuğun nesebi tashih edilmiş neseptir; bu, çocuğu evlilik içinde doğan çocuk ile eşit kılar. Örnȩ̌in ana ve babanın sonradan evlenmesi halinde çocuk ile ana ve baba arasında sahih bir nesip bağlantısı meydana gelir (MK. m. 247). Aynı şekilde hakimin hükmü ile de nesebin tashih edilmesi mümkündür. (MK. m. 249). Diğer bir kısım hallerde ise çocuk ile baba arasında kurulan nesep ilişkisi gayri sa. hihtir. Sahih olmayan nesep ilişkisi hukukumuzda tanıma ve baba. lığa hüküm ile teessüs eder (MK. m. 302).

Bahis konusu ettiğimiz bu yollardan evlenme veya hakimin hükmü ile nesebin düzeltilmesi çocuk bakımından en uygun olan-

Türk işçi kadınların sayısı 4.000 - 5.000 arasında tahmin edilebilir. (Rakkamlar, Auslaendische Arbeitnehmer, 1970, Bundesanstalt für Arbeit, Nürnberg, 29. August 1971 adh yayından alınmıştır). Bu Türk kadınların ne kadannın evli oldugunu tespit etmek mümkün olmamıștr.

${ }^{3}$ Aynı kitap, S. 389. Yayınlanmamıs olan gayri resmi rakkamlara göre sadece Hansestadt Hamburg'da Haziran 1971 - Mayıs 1972 arasında Kiși Halle. ri Memurluğuna 1598 evlenme dışında doğmus çocuk olayı gelmiştir. Bunların 252'sinde baba Alman tabiiyetinde değildir. Jugendamt'in rakkamlarn : 1971 'de 1451 olay, 96 yabanct baba.

4 Alman uzmanlarınca 1960 yllindan sonra hazırlanmıs olan ve Türklerle ilgili bulunan 80 bilirkişi raporu tespit ettik. Bunlarm 62 tanesi aile hukukuna taalluk etmektedir. Aile hukuku konulan içinde de evlenme yolu ile nesebin tashihi, tanuma ve babalığın tespiti önemli bir yer işgal etmek tedirler. Alman mahkemelerinden $1960^{\prime}$ dan sonra verilen Türklerle ilgili 18 karar bulabildik (devletler özel hukuku ile ilgili). Bu kararlarn 16 ta. nesi aile hukukuna ilişkindir ve özellikle evlenme yolu ile nesebin tashihi, nafaka ve velayet konularma taalluk etmektedir. 
larıdır. Çünkü bu hallerde çocuk, hukuken nesebi sahih çocuk halini almaktadur. Buna mukabil evlenme yolu bazen uzun formalite. lerin yerine getirilmesini gerektirir. Hakimin karan ile babaliğa hüküm ise yabancı ülkelerde verilen mahkeme kararlarnnın Türkiye'de tenfizindeki güiçlük nedeni ile pratik değildir. Babalık davası da aynı sakıncaları göstermektedir. Nihayet tanıma, şekil bakımından en müsait bir nesep tesisi yolu olarak gözükmektedir. Fakat tamma ile kurulan nesep sahih olmayan bir neseptir.

Bu yazımızda Türkiye ve Almanyadaki Türklerle Almanların evlilik dışında doğan çocuklarının tanınınası konusu ikili olarak incelenmiş, çeşitli değișik durumlar ve bunlara uygulanacak hukuklar ortaya konarak sonuçlar açıklanmıştır. Amacımız esas itibariyle Türk ve Alman devletler özel hukuku kurallarını eleștirmek veya olması lazım gelen hukuku vazetmek değildir. Esasen kanımıca böyle bir girişim ancak aile hukukuna ilişkin sorunlar bir bütün halinde incelendiğinde fayda sağlayabilir. Buna rağmen, Alman devletler özel hukuku kuralları karşısında Türk devletler özel hukukunun tarafsız bir şekilde gösterilmeğe çalışilması bile bir çeşit eleștiri olarak kabul edilebilir.

\section{ALMAN VE TURK HUKUKLARININ KARŞILAŞTIRIL- MASI :}

\section{A. Sistemler :}

Tanuma bakımından Batı hukuklan iki ana sistem etrafında gelișmişlerdir. Bunlardan bir tanesi tantma sistemidir (Anerkennungssystem). Bu sistemde gerek ana ve gerekse baba ile çocuklar arasında hukuki ilişki tanmma ile kuruhur. Babanın aym zamanda tabii baba olması şartı aranmamıştır. Babanın ana ile birlikte oturmuş olduğunu ispatlaması da gerekmez. Türk-İsviçre hukuku -doğuran kadının tanmasını lïzumlu görmemesine rağmen- bu sistemi kabul etmiștir diyebiliriz. Soy sistemi (Abstammungssystem) adl verilen ikinci sistemde ise gerçi tanıma doğum anundan başlamak üzere baba ile çocuk arasında ilişki dogurmaktadır; fakat bu sadece nafaka ödeme borcu bakımindandir. Alman hukuku son zamanlara kadar bu sistemi kabul etmişti.

5 Dölle, Familienrecht, Bd. I, § 105 I ve 107 II (1965). 


\section{B. Alman Hukuku :}

1 Temmuz 1970'de yuirürlïğe giren 19 Ağustos 1969 tarihli «Das Nichtehelichengesetz» (NEG) ile durum değiști. Bu tarihe kadar Alman hukukunda tanıma esas itibariyle bir delil olarak kabul ediliyordu. Tanımaya genellikle, baba tarafından çocuğa nafaka ödenmesini kolaylaştırıcı bir yol olarak baş vuruluyordu. Babanın yaptığı tanıma beyanı onun tarafından çocuğa ödenecek nafakanın dayanağı idi. Bu tanıma nafaka dışında akrabahk ilişkisi doğurmadığı gibi, şahıs ve aile hukuku bakumından başka hukukî sonuçlar da, örneğin velayet hakkı ve mirasçllık yaratmyyordu. ${ }^{f_{a}}$ Yeni Kanun durumu değiştirmiştir. Bu Kanuna göre, bir kere tanıma çocuğun da muvafakatı ile gerçekleşecektir. Diğer taraftan bu tanıma sonucunda baba ile çocuk arasında akrabalık ilişkisi dogacak, çocuk babanın ve baba çocuğun mirasçısı olabilecektir. Yani maddî sonuçlu nafaka kaldırılmuștır. ${ }^{5 k}$ Soyadı, velâyet gibi konularda yeni kanun ana ile çocuk arasındaki ilişkiye ağırlık vermiş, ancak istisnai hallerde babayı ön plâna geçirmiştir. Alman Anayasasmda yer almış olan evlilik içinde ve dışında doğmus olan çocuklar arasında eşitlik ilkesini (Anayasa m. 6) gerçekleştirmek amacını güden 1969 tarihli Kanun, evli erkeklerin evlilik dışında doğan çocuklarımı tanımalarını da engellememektedir.' Alman hukuku babalığın iptalini kabul etmiştir (BGB m. $1600 \mathrm{f}$ ).

\section{c. Türk Hukuku :}

Türk hukukunda tanıma tek tarafh, yenilik doğuran bir irade beyanı olarak tavsif ediliyor. ${ }^{7}$ Yapılan irade beyanı çocuğun doğumu tarihine kadar giden, geriye dönük sonuçludur. Tanmma ile ço-

5a Bak. Klinkhardt, Die Geltendmachung von Unterhaltsansprüichen nichte. helicher Kinder gegenüber auslaendischen Vaetern, 19 vd. (Heidelberg 1971).

5o Bugünkü hukukda da tanıma olmaksızın herkes nafaka ödeme yüküinü tek tarafl olarak ïzerine alabilir. Odersky, Nichtehelichen-Gesetz, m. 1600 a, N. VI 2 (Bielefeld 1971); Palandt/Lauterbach, Bürgerliches Gesetzbuch, $\mathrm{m}$. 1600 a, N. 1, (München 1972); Siehr, Internationalprivatrechtliches in der jungsten Aenderung der Dienstanweisung für die Standesbeamten StAZ 96 vd. 107 (1972).

${ }^{6}$ Genel olarak bak. Beitzke, Familienrecht, 159 vd. (München 1972); Henrich, Familienrecht, 130 vd. (Berlin 1970). Şekil hakkında, Beitzke, 161.

${ }^{7}$ Akmtürk, Aile Hukuku Dersleri, 309-310 (Ankara 1967); Hegnauer, Schweizerische Zivilgesetzbuch, Das Familienrecht, 2. Abteilung, Die Verwandschaft, 2. Teilband, Das aussereheliche Kindesverhaeltnis, M. 303, N. 5 vd. (Bern 1969). 
cuk ve baba arasında, evlilik içinde doğan çocuk ile baba arasındakine benzer bir hukuki durum yaratılmakta, sadece miras bakjmından evlilik dışındaki çocuk, evlilik içinde başka bir çocuk daha varsa kötï durumda bırakılmaktadır. (MK. 443 II). Hukukumuzda evli erkek ve kadınların zinasından doğan çocuklar tanınamazlar (MK. m. 292).

Türk hukukunda tanıma resmî bir senet veya ölüime bağlı tasarrufla yapilır. (MK. m. 291) (a $^{\mathrm{a}}$ Gerçi tanıma resmi şekilde yapılmaktadı; fakat tek taraflı irade beyan ile vuku bulduğundan tanıyanın gerçek baba olmaması mümkündür. Bu nedenle sonradan tanumaya itiraz edilebilecektir. Bu itirazm 1ttıla tarihinden itibaren üç ay içinde yapılması gerekir. (MK. m. 291 vd.) Hukukumuzda çocuğun tanımaya muvafakatı aranmamıștır.

\section{DEVLETLER ÖZEL HUKUKU KAYNAKLARI :}

\section{A. Alman Hukuku :}

Alman hukukunda tanıma ile ilgili devletler özel hukuku kuralı Medeni Kanuna Giriş Kanunu'nda (EGBGB) vazedilmiştir. Adı geçen Kanun m. 20 evlilik dışı doğan çocuk ile anası arasındaki ilişkileri, m. 21 ise çocuk ile baba arasındaki nafaka mükellefiyetini düzenlemektedir. Maddelerin metinleri şöyledir :

M. 20 : Evlilik dişında doğan çocuk ile anası arasmdaki hukuki ilişki, ananı Alman tabiiyetinde olması halinde Alman kanunlarma göre çözümlenir. Ananun Alman tabiiyetini kaybetmiş. fakat çocuğun bunu muhafaza etmiş olması halinde aynı kưal uygulamir.

M. 21 : Evililik dıșında doğan çocư̆ga karşı babasının nafaka borcu ile ananın gebelik, loğusa ve bakım masraflann karşılama mïkellefiyeti, çocuğun doğduğu tarihte ananın tabijyetinde buIunduğu devletin kanunlanna göre çözümlenir; ancak AIman kanunlarında öngörüilmüşs olanlar aşan iddia ve talepler kabul (ve icra) edilemez.

Görüldüğü gibi m. 21 sadece baba ile çocuk arasındaki nafaka iddialarına uygulanacak kanunu hüikme bağlamıs, tanıma ile ilgili diğer hususlar hakkında bir açıklık getirmemiștir. Bunu tabii karşlamak gerekir. Çünkü, daha önce de belirttiğimiz gibi, eski Alman hukukuna göre, tanıma baba ile çocuk arasında sadece nafaka ba-

${ }^{8}$ Genel olarak bak. Velidedeoğlu, Aile Hukuku, 403 (İstanbul 1965).

8 Velidedeoglu, 409. 
kımından bir sonuç doğurmakta idi ve Giriș Kanunu da yapıldığı tarihde yalnız bu konuyu hükme bağlamak gereğini duymuştu. Bugün durum değişmiştir. 1969 tarihli yeni Kanun, tanımaya nafaka dışında ahkâmı şahsiye alanında da sonuçlar öngördüğünden bu gibi konularda uygulanacak devletler özel hukuku kuralı bakımından bir boşluk ortaya çıkmıștır. Müelliflerin bir kısmı burada, yani baba ile çocuk arasındaki ilişkilerde, nafaka dışında EGBGB $\mathrm{m}$. 19 (ve 20) ye kiyasen babanin hukukunun uygulanmasin kabul etmektedirler.9 M. 19 esas itibariyle evlilik içinde çocuklar ile ana ve baba arasındaki hukuki ilişkilere babanın hukukunun uygulanmasım öngörmektedir. Kıyasen, babanın hukukunun evlilik dıșında do. ğan çocuklara da uygulanmasının menfaatler vaziyetine uygun olduğu ileri sürülmektedir. ${ }^{9 a}$ Hatta Kegel daha ileri giderek, çocuk ile baba arasındaki nafaka ilişkisine bile, madde $21^{\prime}$ in açı ifadesine rağmen, babanın hukukunun uygulanmasına taraftardır. ${ }^{10}$

Diğer taraftan Alman iç hukuku tanımada çocuğun muvafakatini de aradığından EGBGB $\mathrm{m}$. 22'nin kyyasen uygulanması da teklif edilmiștir. Yani evlenme yolu ile nesebin tashihinde nassl ki baba yabancı ise kural olarak onun hukuku uygulandığı halde Alman tabiiyetindeki çocuğa nesebe muvafakat bakımından Alman hukuku uygulaniyorsa, burada da taniyan yabancı olsa dahi, Alman tabiiyetindeki çocuğun Alman hukukuna göre muvafakati aranmalıdır."

9 Soergel/Kegel, m. 21, N. 17, 21, 22, 39; Kegel, Internationales Privatrecht, 366 (München 1972); Bökelmann, Die Bedeutung der Vaterschaft im neuen Recht, StAZ 246, 247 (1970); Henrich, Die Anerkennung nichtehelicher Kinder in Faellen mit Auslandsberührung, StAZ 153 vd. (1971); BGH 14.1.1971. WM 425, 246 vd. (1971). Raape, International Privatrecht 368 (Berlin 1961); Makarov, Grundriss des internationalen Privatrechts, 167 (Frankfurt 1970); Erman/Marquordt, Handkommentar zum Bürgerlichen Gesetzbuch, m. 21, N 5 (Münster 1967). KG, 17.9.1971, FamRZ, 152 (1972); Bay. ObLG, 17.2.1972, FamRZ 321 (1972). Karş. Bay. ObLG, 17.2.1972, FamRZ 318 (1972); Braasch, Die Eintragung auslaenädischer Vaeter von nichtehelichen Kindern in das deutsche Geburtenbuch, Zentralblatt f. Jugendrecht u. Jugendwohlfahrt 183 (1972). Ana hukuku hakkinda bak. AmtsG. Berlin, 2.8.1971, FamRZ 540 (1971).

* Siehr, Auswirkungen des Nichtehelichengesetzes auf das Internationale Privat - und Verfahrensrecht, 64 (Bielefeld 1972); Slehr, Internationalprivat. rechtliches in der jüngsten Aenderung der Dienstanweisung für die Standesbeamten, 25 St AZ 103 (1972). Karș. BGH, 14.1.1971, FamRZ 159 vd. (1971), WM 425 vd. (1971).

${ }^{10}$ Soergel/Kegel, m. 21, N. 18; Kegel, Internationales Privatrecht, 366.

11 Slebr, Age, S. 64 vd. 


\section{B. Türk Hukuku :}

1330 tarihli Kanunun 4. maddesi taraflarn yabanci olmasi halinde nesep ile ilgili davalarda milli kanunun uygulanacağını kabul etmiştir. Bu maddeye dayanarak tanımada da tanıyan ve taninanın ayni tabiiyette olmaları halinde müşterek milli kanunun uygulanması savunulmuştur. Müielliflerin hemen hepsi bu görüșï benimsemişlerdir diyebiliriz. ${ }^{12}$

Tanıyanla tanınan çocuğun ayrı tabiiyette bulunmalan halinde ise görüşler ayrulmaktadır. $O$. Berki, çocuğun menfaatinin bahis konusu olmasi nedeniyle tanınanın kanununun uygulanmasına taraftardır. ${ }^{13}$ Bu hususta çocuğun tanıma zamanındaki millî kanununa itibar edilecektir. ${ }^{4}$ Bu görüşe diğer bazı Türk yazarlan da katılmışlardır. ${ }^{15}$ Kanunlar Ihtilafı adlı kitabında Seviğ çocuğun menfaati nedeniyle onun millî kanununun uygulanmasını kural olarak kabul etmekle beraber, eğer baba Türk ve çocuk yabanct ise babanın hukuku olan Türk hukukuna öncelik tantyor. ${ }^{16}$

Göğer ${ }^{77}$ çocuk ve babanın Türkiye'de veya yabancı bir iilkede olmasına göre bir ayrum yapma taraftarıdır. Yazar, her ikisi de Türkiye'de iseler ve çocuk Türk ise çocư̆un milli kanunu olan Türk kanununun uygulanmasın kabul etmekte, fakat çocuk Türk değil ise yabancı hukukun trygulanmasının Türk devletler özel hukuku sistemi ile pek bağdaștırılamıyacağını beyan etmektedir. Göger, bu takdirde, "dava zamanındaki müşterek ikametgah kanunu veya birlikte bulunulan yer kanunu esaslarna itibar edilmelidir. Bu sistemlerden faydalanılarak Türk kanunlarının uygulanması sağlanmalıdır $n^{\text {18 }}$ demektedir. Çocuk ve baba Türkiye dıșında iseler gene bunlardan birisinin Tủrk olması halinde Göğer, «Türk kanunlarının uygulanmasın istemek devletler hususi hukuku sistemimi-

12 O. Berki, Türk Hukukunda Kanun thtilafları, 101, (Ankara 1971); Figek, Gayrisahih Nesepten Dogan Kanun Ihtilaflar, 60-61 (Istanbul 1954); Uluocak, Kanunlar Thtilafi, 28 (Istanbul 1971); Göger, Devletler Hususi Huku. ku, 213 ve 214. Çocuk ile ana arasındaki ilișkide anamn hukuku: Nomer, Devletler Hususi Hukukunda Nafaka, 57 (Istanbul 1967); Göger, 213.

${ }^{13} \mathrm{~S}$. 101. Fişek, 61 vd.

${ }^{14} \mathrm{~S} .101$

15 Seviğ ve Seviğ, Devletler Hususi Hukuku, 496 (Istanbul 1962); Pigek, 50 ve 60.

${ }^{16} \mathrm{~S} .64$ (İstanbul 1971).

${ }^{17}$ Age., S. 215.

"Aynu yer. 
zin bir icab1" olduğu gerekçesini ileri sürmekte ve "ancak, çocttgun veya babanın davayı gören mahkemenin mensup olduğu devlet tebaasından olması halinde, Türklerin ahkâm-1 șahsiyeleri alanında Türk kanunlan yetkilidir kaidesinde ısrara imkan olmadığı düşïnülmektedir $\aleph^{19}$ görüşünü ilave etmektedir. Şu halde, Göğer'e göre, çocuğun Alman, babanın ise Türk olması halinde esas itibariyle Türk kanunlarının uygulanması gerekir. Fakat konu Alman Mahkemesine intikal ettiğinde artık Türk hukukunun uygulanmasında 1srar etmek gerekmez. Nüfus memuruna intikal eden olaylarda da klyasen Gö̈ger'in ayn görüssde olduğunu söylemek zannımızca müm. kündür. Yani Alman tabiiyetindeki bir çocuğun Almanya'da tanınmasına, baba Türk olsa dahi, Göğer'e göre Alman hukuku uygulanacaktir.

Tanıyan ve tanınan ile ilgili ehliyete müteallik şartlar hususunda her iki tarafa da kendi milli kanunlarnm uygulanması gö. rüşü Türk doktrininde kabul edilmektedir. ${ }^{00}$ Tanımanın șekli lex loci actus kuralı mucibince, yapıldığı yer kanununa göre tespit edilecektir. ${ }^{21}$

\section{c. AnIaşmalar :}

Almanya ile Türkiye arasında aktedilmiş ikili anlaşmalarda tanımaya dair bir hüküm yoktur.

Türkiye ve Almanya bazı milletlerarası anlaşmalara katılmış bulunmaktadırlar :

1. Evlilik Dıșı Çocukların Tanınmalannı Kabule Yetkili Makamların Yetkilerinin Genişletilmesi Hakkındaki 14.9.1961 tarihli Roma Sözleșmesi : Bu Sözleșme, 30 Nisan 1964 tarihli ve 461 numaralı Kanun ile onaylanmıs ve 21.7.1965 den itibaren de yürürlïğe girmesi 23.7.1969 tarihli Bakanlar Kurulu Karar ${ }^{2}$ ile uygun görül. müş̦tür.23 Sözleş̧me, devletler özel hukukunda yerleşmiş bir kural olan hukuki muamelelere şekil bakımından yapıldıklan yer kanununun uygulanmasını öngören locus regit actum kuralını tekrarlamaktadır. Madde 4'e göre «tanıma beyanlan mahalli kanunların ta-

\footnotetext{
19 Ayn yer.

20 Göłger, 213.

21 O. Berki, 102; Sevig, 65. Karş. Göğer, 213; Uluocak, 63; Fişek, 79.

2 V, 8 Düstur 2171. Sözleşme metni, V, 8 Düstur 2794 (1969).

${ }^{23}$ Almanya için bak. BGBl 1965 II 19. Yürürlüğge giriş tarihi, 24.7.1965.
} 
yin ettiği resmi șekilde şahsi haller memurları veya yetkili diğer makamlar tarafindan kabul edilir... Bu beyanlar, beyanda bulunan kişinin kendi memleketinin yetkili makamı önünde yapılmış beyanlar değerindedir».

2. Meşru Olmuyan Çocukların Ana Bakımından Nesebinin Tesisine Ait 12.9.1962 tarihli Brüksel Sözleşmesi. ${ }^{24}$

3. Çocuklara Karșı Nafaka Mükellefiyetine Uygulanacak Kanuna Dair 24.10.1956 tarihli La Haye Sözleșmesi : ${ }^{\star}$

Bu Sözleşme, evlilik dışında doğan çocukların nafaka taleplerinde uygulanacak özel hükümler getirmiştir. Nafaka konusu bìr dava ile çözümleneceğinden ve çocuğun maddî çıkarları bahis konusu olduğundan sorun ayrica milletlerarası kurallarla düzenlenmiștir.

Sözleşmenin 1. maddesine göre, çocuğun kimden ve ne nisbette nafaka isteyebileceğini onun mutad meskeninin bulunduğu yer kanunu tespit edecektir. Aynı kanun, nafaka davasını kimin açabile. ceği ve dava açma süresi konularında da uygulanacaktır. 21 yaşıı doldurmamış kişiler Sözleşmeye göre çocuk olarak kabul edilmek. tedirler.

4. Nafaka Alacaklarının Yabancı Memleketlerde Tahsili ile ilgili 20 Haziran 1956 tarihli New York Sözleșmesi ${ }^{26}$ : Bu Sözleșme nafaka alacaklarına müteallik ilâmlann tenfizi konusunda bir yenilik getirmemekte, esas itibariyle nafaka taleplerinin âkit iilkede sonuçlandırabilmesi bakımından idarî kolaylıklar sağlamaktadır.

\section{TURK BABA TARAFINDAN ALMANYA'DA YAPILAN TA. NIMALAR :}

\section{A. Babanun Bekâr Ananm Alman Tabilyetinde Olması :}

1. Ananın Alman tabiiyetinde olması halinde evlilik dışında doğan çocuk Alman Vatandaşlık Kanunu m. 4'e göre Alman tabiiyetini iktisap edecektir. ${ }^{27}$ Türk Vatandașlık Kanunu çocuk ile tabii

24 Onaylayan K, No. 578, 8 Nisan 1965, V 4 Düstur 1002 (1965) ve Bak. Kur. Kar., 28.5.1965, V. 4 Düstur 3197 (1965). Almanya için bak. BGBl. 1965 II 17.

25 Resmi Gazete, 24 Aralık 1971, Almanya için BGBI 1961 II 1013.

${ }^{26}$ Resmi Gazete, 18 Mart 1971. Rezakı, Nafaka alacaklarmın yabancı ülkelerde tahsili ile ilgili Sözleşme, 62 Ad. Der. 481 vd. (1971). Almanya için bak. BGBl. 1959 II 149.

${ }^{27}$ Beitzke, Familienrecht, 179 (München 1972). 
baba arasındaki nesep bağının teessüsüne kadar yabancı ülkede doğan çocuklara Türk tabiiyetini vermemektedir. Bundan dolayı çocuk Türk hukukuna göre de Alman tabiiyetindedir. Alman devletler özel hukuku tanımada babanın hukukunun uygulanmasını kabul et. tiğinden bu konuda Türk hukukuna bakmak gerekir.

Türk hukukunda üstün görüș : Türk hukukunda tanıma konu. sunda genellikle çocuğun hukukunun uygulanması görüşü savunulmaktadır. Yani Türk hukuku, uygulanacak hukuk bakımından meseleyi Alman hukukuna geri göndermektedir. Alman EGBGB m. 27 bu geri göndermeyi kabul eder. ${ }^{28}$ Şu halde tanımanın Alman hukukuna uygun olarak yapılması gerekir. «Tanımanın ana veya baba nam ve hesabına kimler tarafından yapulabileceği» ve etanımaya itiraz edilip edilemiyeceği», "kimlerin itiraz hakkını haiz olduklan", «itirazın müddete tabi olup olmadığ, tabi ise müddetin neden ibaret olduğu" konular ${ }^{29}$ hep Alman hukukunca çözümlenecektir. ${ }^{2{ }^{2 a}}$

Yeni Alman hukukunda baba tarafından yapılan tanımanın ge. çerli olması için çocuğun muvafakati aranmıștır. Mamafih bu mu. vafakatin babanın tanıma beyan ile aynı anda verilmesi gerekmez; çocuk 6 ay içinde tanımaya sonradan da muvafakatini bildirebilir (BGB m. $1600 \mathrm{c}$ ve $1600 \mathrm{e}$ III). Çocuğun muvafakatini hemen bildirmemesi uygulanacak hukuk bakımından ilginç bir durum ortaya çrkarmaktadır. Şöyle ki: Türk Vatandaşlık Kanunu m. 2'ye göre yabancı anadan evlilik dışında doğan çocuk, nesebin tashihi, babalığın hükümle tahakkuk etmesi ve tanıma yollanndan biriyle Türk vatandaşına nesep bağı ile bağlanırsa, doğumdan başliyarak Türk vatandașı olur. Acaba burada amılan tanıma ile ne kastedilmiștir?

Vatandaşlık Kanununa göre tanımadan bahsedebilmek için devletler özel hukuku kurallarına deģil, Türk iç hukuk kurallarına bak-

${ }^{28}$ Soergel/Kegel, m. 27'de yapılan açıklamalar.

${ }^{29}$ o. Berkl, 101.

29a Alman mahkemeleri babanin Türk ve ananın Alman tabiiyetinde olmasi halinde genellikle Alman hukukunu uyguluyorlar. Nitekim son zamanlarda OLG Celle, baba hukuku olan Türk hukukunun çocuğun hukukuna atıf yapması nedeni ile Alman tabiiyetinde olan çocuğun hukukunu tanımaya tuygulamıștı (14.6.1972, DA Vorm., 490 (1972) ). Buna mukabil LG Duisburg atfın kabul eđ̛ilebilmesi için Türk hukukunda bir kanun hükmünün bulunmasinı aradi ve sadece Yargitay uygulamasına dayanarak Türk hukukunda atfin mevcut olduğu sonucuna iltifat etmedi. Bu nedenle de tanıma konusuna Türk hukukunun tatbik edilmesi gerektiğini ifade etti. Mamafih mahkeme kamu düzeni gerekçesi ile ihtilafı Alman hukukuna göre çözümledi. (23.6.1972, StAZ 16 (1973)). 
mak gerekmektedir. Türk Vatandaşlığı Kanunu'nun Uygulanmasına Ilişkin Yönetmeliğin 5. maddesi bunu, «Medeni Kanunu hükümlerine uygun olarak... Türk uyruklu erkeğe nesep bağı ile» bağlanmak șeklinde ifade etmektedir. ${ }^{30}$ Vatandaşlık kamu hukuku alanına giren bir konu olduğundan, kamu hukuku sorunlarnnm devletler özel hukuku kuralları ile çözümlenemiyeceğini ileri sürmek ve yukarıdaki sonuca teorik yönden de varmak mümkündür. ${ }^{3 t}$ Karşıt görüş kabul edilse idi tanımaya, Türk devletler özel hukukuna göre çocuğun hukuku, yani Alman hukuku uygulanacağından ve bu hukukda da çocuk muvafakatini bildirmedikçe tanıma gerçekleşmediğinden Türk tabiiyetini iktisap anı ileriye itilmiş olacaktı.

Türk Medeni Kanunu tanımanın geçerli olması için baba tarafindan (veya babanın vefatı veya temyiz kudretini daimi olarak kaybetmesi hallerinde babanın babası tarafindan) resmi senet veya ölüme bağlı tasarrufla yapılması gerektiğini hükme bağlamıștır (m. 291 I ve II); ayrica çocuğun muvafakatı gerekmemektedir. Bu durumda babanın Almanya'da şekle uygun bir surette tanmma beyanında buiunması, çocuğun rızası olmadığı için Alman iç hukuku bakı. mından geçerli bir tanıma sonucu doğurmamasına rağmen, Türk Vatandaşlık Kanưnu'na göre muteber sayılacak ${ }^{31 a}$ ve çocuk doğum. dan başlamak üzere Türk tabiiyetini kazanacaktır. Çocuğun tabiiyeti Türk olunca Türk devletler özel hukukunda o zamana kadar çocuğun tabiiyeti olan Alman hukukuna yapılan atıf düșecek, Alman mahkemeleri tarafından da artık Türk hukukunun uygulanması gerekecektir. Bunun, çocuğun rızası bulunmaksızın tanımanın Alman hukukunda da geçerli olduğu sonucunu doğurmayacă̆ı EGBGB m. 22'ye kıyasen ileri sürülmektedir. M. 22, evlenme yolu ile nesebin düzeltilmesine ilişkindir ve eğer çocuk Alman tabiiyetinde ise bu konuda onun da rızasının alınmasını âmirdir. Türk hukukuna uygun bir tanıma ile çocuk Alman tabiiyetini kaybetmediğinden Almanya'da Alman hukukunưn uygulanmasına devam olunur. Diğer bir ifade ile tanımanın Almanya'da geçerli olabilmesi için gene de çocuğun muvafakati aranır.,

\footnotetext{
30 Medeni Kanun hükümleri dışında da özel kanunlar Türk erkek ile çocuk arasında nesep bağının kurulmasına imkan verdiğine göre bu maddenin ifadesi yeterli değildir. Bak. Ayiter, Das Staatsangehörigkeitsrecht der Türkei, 33 vd. (Berlin 1970).

31 Aynı görüis Uluocak, Türk Vatandaşlık Hukuku, 29 (Istanbul 1968).

31. Aynı görüss, Slehr, 25 StAZ 97 vd., 105 (1972).

32 Siehr, Agm., S. 104 ve orada not 87.
} 


\section{Tanımanın Sonuçlanı (Hükümleri) :}

a) Ana ile çocuk arasındaki sonuçlar : Alman EGBGB m. 20'ye göre ana Alman tabiiyetinde ise çocuk ile anası arasındaki ilişkile. re ananın hukuku, yani Alman hukuku uygulanır. Ananın çifte ta. biiyetli olması halinde eğer bu tabiiyetlerden biri Alman tabiiyeti ise gene Alman hukuku uygulanacaktır. ${ }^{33}$ Ş halde, ananın velâyet hakk1, çocuğun ikametgâhı, ismi, ${ }^{34}$ ana tarafindan ödenecek nafaka ve ananın vazifeleri (ve kural olarak çocuk ile ana arasındaki miras ilişkileri) hep ananın hukuku olan Alman hukukuna göre çözüme bağlanırlar. ${ }^{35} \mathrm{Bu}$ konularda Türk hukukuna atıf yapılmadığından Türk hukuku uygulama alamı bulmaz.

b) Çocuk ile baba arasındaki sonuçlar : Tanımanın çocuk ile baba arasındaki sonuçlan bakımından Alman müellifleri babanın hukukunun uygulanmasım savunmaktadırlar. ${ }^{36}$ Böyle bir durumda Türk devletler özel hukuku kuralları da, çocuk tanıma ile Türk tabiiyetini kazanmı olduğundan, onun hukuku olan Türk hukukunun uygulanmasını önermektedir. Gerçi tarafların başka tabiiyette olmaları halinde tanımaya uygulanacak hukukun çocuğun hukuku veya babanın hukuku olduğu șeklinde iki ayr görüiş mevcuttur. Fa. kat tanımanın sonuçları bakımından bu görüșler fïlen birleşmekte. dir. Çünkü, çocuk babasına nisbetle Türk tabiiyetini kazandığından (Vat. K. m. 2), iki görüş arasında bir fark kalmamaktadır..$^{37}$ Böyle bir tanzim tarzının çocuğun çkarına da uygun olduğu söylenebilir. Tanıma ile ilgili bașlıca sonuçlar şunlardır :

(1) Soyadı : Çocuk Türk MK m. 312'ye göre babasının aile ismini taşır. Bu tanzim tarzı çocuk Almanya'da kaldığı sürece Alman. ya'da güçliuk doğurabilir. Çünküi Alman devletler özel hukukunda çocuk ile ana arasındaki ilişkilere ananın hukuku uygulanır. (EGBGB, m. 20). Alman iç hukukuna göre ise evlilik dışında doğan çocuk anasının soyadını taşır (BGB 1617). Şu halde çocuk bir yan-

$33 \mathrm{Bu}$ uzun süreden beri doktrinde ve mahkeme uygulamasında kabul edilen üstün görüiştür. En son kararlar: BGH, 18.10.1968, FamRZ, 28, 30 (1969) (Gamillscheg'in notu, ayni Dergi, S. 80). NJW 369 (1971), MDR 126 (1969); Bay OLGZ, 1968, 262, 265; OLG Karlsruhe, FamRZ, 161, 162 (1969) ve Soergel/Kegel, S. 736, not 7'deki göndermeler. Karşıt göriiş, Kegel, Age., s. 177 .

${ }^{34}$ AIman iç hukukuna göre evlilik dışında doğan çocuk anasının soyadını ta. șir, BGB 1617, Beitzke, 180 (1972).

35 Soergel/Kegel, m. 20 , N. $10 \mathrm{vd}$.

${ }^{36}$ EGBGB m. 20'ye kıyasen, Soergel/Kegel, m. 21, N. 17, N. 39 vd. Siehr,

${ }^{37}$ Bak. Sevig, 65. 
dan anasının soyadını taşıyacak, dił̌er yandan da babası ile olan ilișkilerinde Türk hukukuna yapılan gönderme nedeni ile babasının scyadımı taşımak durumunda kalacaktır. ${ }^{38}$

(2) Mirasçllı : Çocuk ve baba birbirlerinin mirascısı olabileceklerdir. Bu her iki hukuk sisteminde de kabul edilmiș bir sonuçtur. Mamafih Türk hukuku, babanın evlilik içinde başka çocukları mevcut ise, tanıma ile nesep bağı kurulan çocuklara yarn nisbetinde miras hakk tanımaktadır. Bu kuralın Alman kamu düzenine aykırı olması mümkündür. ${ }^{39}$

(3) Velâyet : Türk hukukunda velâyet hakkı tanuma ile otomatik olarak babaya geçmez. Doğumla birlikte çocuk anasının velâyeti altına da kendiliğinden girmez; mahkeme velâyeti ana veya babadan birine verebilir veya bunların dıșında bir vasi tayin edebilir." (MK. m. 312, 298) Çocukla ana ve baba arasındaki şahsi müna. sebetlerin idamesinde de hakim karar vermek durumundadur (MK. m. 313). Halbuki Alman hukukunda ana doğumla birlikte çocuk üzerinde velâyet hakkınt elde etmektedir (BGB. m. 1705). Veli olarak ananın tanıma anından sonra çocuk adına yaptığı hukuki muamelelerin Türk hukukunda geçerli saylmaması gerekir."

(4) Babanın görevleri : Babanın evlilik dışında doğan çocuğuna karşı olan vazifeleri Türk hukukunda tıpkı sahih nesepli ço. cuklarnna karşı olan vazifeleri gibidir. Baba çocuğa bakmak ve onu yetiștirmekle mükelleftir. Velâyet hakkı babaya verilmemiş olsa bile bu mükellefiyetleri babanın yerine getirmesi gerekinaz (MK. m. 312). Babanın nafaka mükellefiyeti de evlilik içinde doğan çocuğuna karşı mükellefiyeti gibidir (MK. 261). Fakat bu konu ayrica incelenmeyi gerektirmektedir.

(5) Nafaka: Bu konuda daha önce değindiğimiz 24.10.1956 tarihli Çocuklara Karşı Nafaka Mükellefiyetine Uygulanacak Kanuna Dair 24.10.1956 tarihli La Haye Sözleşmesi özel hükümler getirmiştir. Bu Sözleşme, son zamanlara kadar Türkiye'de geçerli değildi; 1482 saylı Kanunla onaylanı 24.12.1971 tarihinden itibaren yürürlư̆ğe girdi. Mamafih Sözleşmenin getirdiği kuralların bir ülkede

\footnotetext{
${ }^{36}$ Slehr,

${ }^{39}$ Nesep ile ilgili kurallarin mi yoksa miras hukuku kurallannm mı uygu. lanacağ hakkında bak. Sevi⿺, 65.

40 Akutürk, 335. Bunu Klinkhardt da belirtmiștir (S. 26).

${ }^{41}$ Evlilik dışında doğan çocukların temsili konusu ayı bir yazımızda ince lenecektir.

2 Akmtürk, 336.
} 
uygulanabilmesi için diğer ilgili ülkenin de Sözleşmeyi imzalaması şart olmadığı gerekçesi ile Alman doktrini ve mahkeme uygulaması bir süreden beri bu Sözleșme hükümlerinin, mutad meskeni Almanya'da olan çocuklara uygulanmasını kabul etmektedir. ${ }^{43}$ Nitekim Türklerle ilgili bir olayda Berlin mahkemesi ayni yönde karar ver. miști : Davaya mesnet olan olayda Türk ananın bir Alman erkekten evlilik dışında çocuğu olmuş ve Alman erkek, çocuğa nafaka ödemeyi kabul etmişti. Türk ana yeni Evlilik Dıșı Çocuklar Kanunu (NEG) yürürlüğe girdikten sonra nafaka kararının NEG m. 12/14'e göre değiștirilmesini istedi. Alman erkek burada EGBGB m. 21'in, yani ana hukuku olan Türk hukukunun uygulanmasını savundu. Mahkeme bunu reddetti. Çünkü olay nafaka ile ilgilidir ve La Haye Sözleşmesine göre, bu Sözleşme Türkiye'de yürürlükte olmasa bile «mutad mesken» hukukunun uygulanması gerekir." Sözleşmeye göre, çocuğun kimden ve ne nisbette nafaka talep edebileceği, davanın kimin tarafından açılabileceği ve dava açma süresi konularında hep çocuğun «mutad meskeni»nin bulunduğu yer kanunu uygulanır.

a) Türk erkeklerinin (Almanyadaki Türk ișçilerinin) Alman (ve Almanya'da yașıvan Türk) kadınlarından evlilik dışında doğan çocukları genellikle Almanya'da yaşamaktadırlar. Yani bunların mutat meskenleri, ana orada yaşadığı sürece Almanyadadır. Bu nedenle Alman devletler özel hukuku kuralları tanımaya bașka bir hukukun uygulanmasını öngörmüş olsa dahi tanıma La Haye Anlaşması gereğince Alman iç hukukuna uygun bir şekilde yapılmalıdır. Diğer bir ifade ile çocuğun muvafakatinin tanımaya inzimam etmesi gerekecektir. Ancak Alman hukukuna uygun bir tanıma tahakkuk ettikten sonradır ki çocuk nafaka iddiasında bulunabilir. ${ }^{45} \mathrm{Bu}$ nafakanın miktarı ve süresi de Alman hukukuna göre çözümlenecektir. ${ }^{46}$

Alman mahkemelerinin nafakaya ilişkin kararlarının Türkiye'de tenfiz edilmesi iki ülke arasında ikili veya çok taraflı bir tenfiz an-

${ }^{43}$ Siehr, Haager Unterhaltsstatutsabkommen und gerichtliche Vaterschafts. festsellung, FamRZ, 398 vd. (1971). AmtsG München, 12.1.1971, aynı Dergi, S. 458. OLG München, 23.7.1971, FamRZ, 542 (1971). Aksi yönde karar: OLG Karlsruhe, 18.1.1971, FamRZ 459 vd. (1971) ve bunun eleștirisi: Jayme/Siehr, ayn Dergi, S. 462. Henrlch, 25 StAZ 7 (1972).

44 AmtsG. Berlin - Tempelhof - Kreuzberg, 1.12.1970, FamRZ 105 (1971),

${ }^{45}$ Siehr, yuk. nt. 43.

${ }^{46}$ Nafaka taleplerinde yetkili mahkeme için bkz. ZPO m. 23 a. Nafaka konusu ayrı bir yazımızda incelenecektir. 
laşması bulunmadığından mümkün değildir. 1956 tarihli New York Anlașması burada uygulanmaz.

b) Çocuk Türkiye'de yaşamakta ise nafaka bakımmndan La Haye Anlaşmasına göre Türk hukuku uygulanır. Türk iç hukukunda evlilik dışında doğan çocuğu tanıyan babanın nafaka mükellefiyeti sahih nesepli çocuğuna karşı olan mükellefiyeti gibidir (MK. m 261).

3. Ana hukuku ile baba hukuku çelişkisi : Örneğin Alman hu. kukunda çocuk anasının soyadını, Türk hukukunda babanın soy. adını alır. Bizde çocuk üzerindeki velâyet hakkı hakimin hükmü ile belli olur; halbuki Almanya'da velâyete ana sahiptir. Bu gibi ve benzer konularda çoğunluk ana hukukuna taraftardır; Kegel'e göre baba hukuku esas olmalıdır.,

4. Sonradan vuku bulacak tabiiyet değișikliklerinin uygulanacak hukuku etkilemesi Alman doktrininde savunulmuștur.tb Örneğin, tanıma ile çocuk Türk vatandaşh̆ğın kazandığından babası ile olan ilişkilerinde kendisine Türk hukukunun uygulanacağını söylemiştik. Eğer çocuk sonradan her hangi bir nedenle Türk vatandaş. lığını kaybedip Alman vatandaşlığını kazanırsa ilişkilerin artık Al. man hukukuna göre dïzenlenmesi mümkün olabilir. Buna mukabil ana ile çocuk arasındaki ilişkilere de, ananın sonradan Alman tabiiyetini kaybedip Türk vatandaşlı̆̆ını kazanması halinde Türk hukuku uygulanabilecektir.

Mamafih tanımaya itiraz davası bakımından bir özellik vardır. Bu dava tanımanın yapıldı̆̆ı andaki bir hususa ilişkin olduğundan konu tanımanın yapıldı̆̆ı andaki kanun hükümleri ile çözüme bağlanmalıdır. ${ }^{49}$ Türk doktrininde Berki «tanımaya itiraz edilip edilemiyeceğini, kimlerin itiraz hakkmı haiz olduklarını ve itirazın müddete tabi olup olmadığın, tâbi ise müddetin neden ibaret olduğgr

${ }^{47}$ Çünkü burada babanun duxumu önemlidir. Soergel/Kegel, m. 21, N 25. Fakat çoğunluk ananın hukukuna üstünlük tanır: Staudinger/Raape, Kom. mentar zum Bürgerlichen Gesetzbuch, S. 530 (Berlin 1931); Erman/Mar. quordt, m. 21, Bem. 5; Neuhaus, Die Verpflichtungen des unehelichen Va. ters im deutschen internationalen Privatrecht, 14 (Stuttgart, 1953); Beitzke, Vaterschaftsanerkenntnisse von Auslaendern vor dem Jugendamt, 49 Zentrallblatt f. Jugendrecht und Jugendwohlfahrt, 177 vd., 184/185 (1962). Bu konuda Türk baba ile ilgili bir davada Berlin Mahkemesi ana hukukuna üstüinlük tammıştı (AmtsG. Berlin, 2.8.1971, FamRZ 540 (1971).

48 Soergel/Kegel, m. 21 N 26, 28, 29 ve orada yaplan göndermeler.

Q Siehr, Age., S. 67. 
nu» hep tanıma zamanındaki millî kanunun çözümleyeceğini ifade etmiștir..$^{50}$

B. Babann Evli, Ananm Alman Tabilyetinde Olması (ve fücur mahsulü çocuklar) :

1. Alman devletler özel hukukunun tanumada babanin hukukuna atıf yaptığını belirtmiștik. Baba Türk olduğuna göre tanımada Alman mahkemeleri Türk hukukunu bir bütün olarak uygulayacak. lardır. Yani, Türk hukuku başka bir hukuka atıf yapmışsa bu da nazara alınacaktır.

2. Türk devletler özel hukuku : a) Ustün görüş : Türk devletler özel hukukunda üstün görüş tanımada çocuğun hukukunun uygulanması şeklindedir. Bu nedenle çocư̆un tabiiyetine bakmak gerekir. Çocuğun Türk vatandaşlı̆̆ım kazanabilmesi için tanımanın Türk hukukuna uygun bir biçimde yapılması gerektiğini Vatandaşlık Kanunu'nun hükme bağladığını açıklamıştık. Türk Medeni Kanunu evli erkek ve kadınların zinasından doğan çocukların tanın. masını yasakladığından bu gibi çocukların Türk vatandașlığını iktisap etmeleri -Alman hukukunda bu çeşit tanıma mümkün olmasma rağmen-- kabil değildir. Esasen tanımadan önce bu çocuklar Türk tabiiyetini kazanamiyacaklarından kendilerine Türk hukuku uygulanamaz.

Türk devletler özel hukukunda çocuğun hukuku kuralı tasvip görmesine rağmen bu kurala kamu düzeni bakımından istisna da yapılmaktadır. Mamafih zina mahsulï çocukların tanınmasının Türk kamu düzenine aykırı olup olmadığı konusunda farklı görüșler ortaya konmuştur :

Bir kısım yazarlar, yetkili kanun mümkün kılsa bile, zina ve fücur mahsulü çocuklarm tanmmasmı Türk kamu düzenine aykırs görmektedirler. ${ }^{52}$ Yani, Tüirk baba Alman hukukuna göre muteber bir șekilde çocuğunu tanısa ve hukuki baba olarak orada tescil edilse bile bu babalik Türkiye'de geçerli değildir.

Türk Medeni Kanununda, evli erkek ve kadınların zinasindan doğan çocukların tanımmalarının yasaklanmış olması (MK m. 292),

50 O. Berki, 101. Türk hukukunda babanın itiraz hakkı düzenlenmemiştir. Bu konuda irade fesadı ile ilgili Borçlar Kanunu hükümleri uygulanabilir. Bak. Velidedeoğlu, 414; Hegnauer, m. 306, N 27 vd.

92 O. Berki, 101; Fişek, 76. Karş. Uluocak, 22. 
meşru aileyi korumak içindir. ${ }^{53}$ Sahih nesepli çocukların evlilik dr. \$̧ında doğanlara karșı korunması amacı kanımızca bugün değerini yitirmektedir. Ísviçre Federal Mahkemesi de bu maddenin Isviçre. deki karșılığı olan 304. maddeyi geniş yorumlamak suretiyle bu modern görüşïi temsil etmektedir. Gerçekten Federal Mahkeme son zamanlarda verdiği önemli bir içtihat değiştirme karannda erkeğin sadece cinsi münasebet anında (doğum anında) evli olmasının tanımayı engelliyeceği görüuşünüi açklamıștır. Mahkemeye göre, kadın bakumindan tabii analik sistemi kabul edildiğinden esasen onun bakımından tanıma bahis konusu olmayacaktır. Babanın sonradan evlenmiş olması da tanımayı engellememelidir..$^{44}$

Gerçi Türk müelliflerinin çoğunluğu evli erkeklerin tantmasınłn Türk kamu düzenine aykırı olduğu görüişündedirler, fakat $G o ̈$. ğer, bu görüșïin «fiilî birleșmelerden doğan çocuklarun neseplerinin tashihini öngören af kanunları karşısında yeri olup olmadı̆̆ı cayi sualdir" demektedir. ${ }^{55}$ Mamafih yazarn fikrince "yetkili yaban. cı kanuna göre zina mahsulü çocukların tanınmasının da Türk ka. mu düzenini ihlal etmemesi lazımdır». ${ }^{56}$

Evlilik dışında doğan çocukların tescili ile ilgili olarak zaman zaman çıkartılan kanunlara dayanıp MK m. 292'deki hükmün ka. mu düzenini ilgilendirmediğini savunmak tereddütler dogurabilir.,

53 Akmtürk, 312; Velidedeoğlu, 404.

54 BGE 95 I 384 vd., 1969. Olayda bahis konusu olan bir Italyan aile idi. Ka. n bekâr bir Isviçreliden çocuk sahibi oldu. Italyan erkek çoctư̆u reddetti. Isviçreli ise, sonradan başka bir kadınla evlenmiş olmasına rağmen ço. cuğu tanıdı. Karș. Velidedeoğglu, 409.

55 Gögrer, 215.

\$s. 215.

"Fiilî birleşmelerle bunlardan dợan çocukların tesciline dair en son çlkark. lan kantun 1965 tarihlidir (No. 554, yaym t. 8 Nisan 1965). Bu'kanunun 1. maddesi, evli bir erkekle evli olmayan bir kadının karı koca gibi yașamalarnndan doğmuş olan çocuklarin nesebi sahih olarak kadın ve erkeğe iza. fetle tescil edilece gini hükme bağlamistr. Bu suretle anzi birleşmelerden doğan çocuklar esas itibariyle bu kanunun kapsamı dıșında kalmaktadır. Diğer taraftan kanun bu çocukların nesebi sahih çocuk olarak tescilini öngörmektedir. Halbuki evlilik dışında doł̆an çocuklarn Medeni Kanunun tanımaya ilişkin hükümolerine göre tescili ancak gayri sahih nesepli olarak yaplabilir.

Madde 3 tescil muamelelerinin ifasin ilgililerin mahallin en büyük miilkiye amirinden bir dilekçe ile isteyeceklerini söylemektedir. Yabancı ìlkede konsolosluklar en yüksek mülkiye amirinin görevlerini yerine ge. tirmektedir. 
Bilakis, aile düzenini savunan bu maddenin mutlak uygulanmasım sağlamak için, yurdumuzun şartlarının ortaya çıkarttığı evlilik dışı çocukların çıarlarının da korunması amaciyle zaman zaman dü. zeltmelere gidildiği söylenebilir.

Bizce zina mahsulü çocukların kanun koyucunun iradesi dışında tanınması Medenî Kanunun ifadesi karşısında bugün dahi Türk kamu düzenine aykundır. ${ }^{58}$ Ancak arızi kanunlar esasen nesebin tashihini mümkün kılmakta iseler, bu takdirde evli Türk erkeğin Almanya'da çocuŏunu tanıması Türk kamu düzenine aykırı olmamak gerekir.

b) Azmlık görüşü : Türk hukukunda savunulan bir diğer görüşe göre tanımada çocuğun hukuku değil, baba Türk ise Türk hukuku uygulanacaktır. Göğer bu görüșüne, «ancak, çocuğun ... dâvayı gören mahkemenin mensup olduğu devlet tebaasından olması halinde ${ }^{59}$ Türk kanunlarının uygulanmasinda israr edilmemelidir, diye bir istisna getirmektedir. Kendisine göre Alman olmayan kadınlardan doğan çocuklarını Türk erkek, Almanya'da tanıyamıyacaktır.

3. Alman mahkemelerinde Türk kamu düzeni : Acaba Alman hukukunun Türk kamu düzenine aykır olması nedeniyle Alman nüfus memuru Türk babayı nüfusa kayıttan imtina etmeli midir? Diğer bir deyişle, Alman yargıçları yabancı kamu düzenini nazara almak durumunda midırlar?

Kural olarak Alman yargıçlan yabancı hukuku uygularken sa. dece Alman kamu düzenini nazara almak durumundadırlar ${ }^{\text {to }}$ (EGBGB m. 30). Yabancı bir ülkenin kamu düzenini de nazara alıp almamakta Alman yazarlar farklı görüştedirler. Bir kısım müellif. ler eğer yabancı kanunlar ihtilafı kuralı açıkça kamu düzenini be yan etmişse, ${ }^{61}$ diğer bir kısım müellifler yabancı hukuk bașka bir hukuka atıf yapmışsa ve bu hukuk atıf yapan ülkenin kamu düzenine aykır ise yabancı kamu düzeninin nazara alınmasın $1^{62}$ savun.

\footnotetext{
58 Isviçrede aynı görüş: Vlscher, Internationales Privatrecht, 620 (Schweizerisches Privatrecht, Band I, Basel, Stuttgart, 1969).

59 Göğer, 215.

${ }^{60}$ Soerget/Kegel, m. 30, N. 3 ve 23; Raape, Internationales Privatrecht, 97 (1961); Dölle, Internationales Privatrecht, 113 vd. (Karlsruhe 1972).

${ }^{61}$ Raape, (Staudingers Kommentar BGB, Bd VI, § 27, S. 752 vd. Berlin 1931);

Raape, Internationales Privatrecht, 97 vd., n, 96.

${ }^{62}$ Dölle, Internationales, Privatrecht, 113 vd.
} 
muşlardır. Çoğunluk, yabancı kamu düzeni anlayışının tesbitindeki güçlüğe rağmen bunun nazara alınmasim uygun görmektedir.63

Türk kamu düzenine aykun bir durumun Alman yargıcı tarafindan nazara alımmasinin Alman kamu düzenine aykın olup olmayacağı Alman hukukunda tartışılmıştır. Aykurılik halinde Alman kamu düzeninin üstün tutulması gerektiği görüşü genellikle ileri sürililmektedir.t

Eğer Türk hukukundaki zina mahsulü çocuklarn tanınamamas1 kuralı Alman kamu düzenine aykırı görülecek olursa Türk erkek Almanyadaki nüfus kütüğüne hukuki baba olarak kaydolunabilecektir. Bunun bir takım hukuki sonuçları vardır:

(1) Türk tabiiyetindeki erkek Almanya'da zina mahsulü çocu. gun Almanya'da hukuken babası olduğu halde Türkiye'de değildir. Bundan dolayı Türkiye'de kendisi aleyhine nafaka davası açılamı. yacaktır; halbuki Almanya'da böyle bir dava açılabilir. (Yuk. IV A 2).

(2) Babanın akrabalan ile çocuk arasında Türk hukukuna göre akrabalik ilişkisi doğmaz.

(3) Çocuk Türkiye'de babasının aile ismini taşıyamaz.

(4) Türk hukukunda baba ile çocuk arasında miras hukuku ilişkisi teessüs etmez. Almanyada böyle bir ilişki doğmaktadir.

(5) Çocuk Türk vatandaşlığını kazanamaz.

c. 1 Temmuz 1970'den Önce Doğan Cocuklar (Ana Alman, Baba Türk) :

1969 tarihli NEG Türkleri yakından ilgilendiren önemli bir hüં küm getirmektedir. Yukarıda açıkladığımız gibi Alman hukukunda eskiden sadece nafaka sonucunu doğuran tanımalar biliniyordu.

a3 Soergel/Kegel, m. 30, N 26, m. 27, N 37; Melchior, Grundlagen des Inter nationalen Privatrechts, 211 vd. (Berlin 1932); Kegel, Internationales Privatrecht 51 vd.

${ }^{64}$ Kegel, Internationales Privatrecht 151; Melchior, 214. LG Duisburg'un bu yöndeki kararı: Olayda Türk erkek evli idi. Evli erkeğin evlilik dıșında doğan çocuğunu tanıyamryacă̧ı şeklindeki Türk hukuk kuralının Alman kamu düzenine aykır olđuğu gerekçesi ile mahkeme Alman hukukunu uyguladı ve Türk erkę̆in baba olarak nüfus siciline kaydolmasına karar verdi (23.6.1972, StAZ 16, 1973). 
1969 tarihli Kanunun 12 nci maddesinin 3. ncii fikrası bu Kanunun yürürlüğe girme tarihinden önce yapılan tanımaların bundan böyle baba ile çocuk arasında geçmişe şamil olarak diğer ilişkileri de doğuracağını, yani hukuki bir tanıma sonucu yaratacağını hükme bağlamıştır. Şu halde andı̈̆ımız maddeye göre, 1970'den önce nafaka ödemek amacı ile tanıma beyanında bulunan Türkler ile çocuklar arasında artık şahsi ilişkiler de doğacak, örneğin baba ile akrabalık ilișkileri teessüs edecektir. Bu, yapılan irade beyanna, beyanda bulunan şahsın istemediği sonuçları yüklemektedir. ${ }^{65}$

Bu çeşit tanmmaların pek çok olduğu anlaşılmaktadır. Çünkü eskiden Almanya'da evlilik dışında doğan çocuklara nafaka ödenmesini sağlamak için babalık davası gibi masraflı bir yola gitmektense $e^{\text {*o }}$ tanıma yoluna gidilmesi tabii babalara tavsiye edilmekte idi. Evli bir erkeğin bu amaçla tanıma beyaninda bulunması mümkündü. Hatta tabii baba olmayan kişiler bile yardım amaciyle tanımada bulunuyorlardı. Çünkü bu tanıma, tanıyan ile çocuk arasında malî ilișkiden bașka bir ilişki doğurmuyordu. Hatta eski hukukda tabii baba tanıma beyanında bulunmaksızın mahkeme kararı ile çocuğa nafaka ödemeye mahkûm edilebiliyordu. Bu nedenle de nafaka ilişkisinin aile hukukundan değil, borçlar hukukundan doğan bir borç yarattığı ileri sürülmüsstii. ${ }^{77}$ Yeni Kanun, yapılan irade beyanlarma yapanın arzu ettiğinden daha kapsamlı sonuçlar tanımaktadır. Mamafih, kanun böyle bir durumda babaya babalı̆̆ın ref'i davası açmak hakkını da vermektedir. ${ }^{68}$ Fakat hata iddiası ile irade beyanınm (hukuki muamelenin) iptali yoluna gitmek mümkün olamıyacaktır. Gerçi BGB m. 119 ve 123 hata halinde iptali düzenlemektedirler ve buradaki saik hatasını esaslı bir hata olarak da kabul etmek mümkündür. ${ }^{69}$ Fakat 1969 tarihli Kanun konuyu açıca düzenlediğinden artık hata iddiasının yapılamıyacağı savunulmuş̧ur. ${ }^{70}$

${ }^{65} \mathrm{Bu}$ konuda son zamanlarda yaymlanan şu yazyya da bak. Henrich, Welche Bedeutung hat Art 12 \$ 3 des Nichtehelichen gesetzes in Faellen mit Aus. landsberührung? 25 StAZ $7 \mathrm{vd}$. (1972);

ob Babalık davası ayrıca yabancı ilâmlann tenfizi sorununu ortaya çıaracak tır. Bak. Giriş.

${ }^{67}$ Bak. Staudinger, Kommentar, m. 1708, N. 7 vd. Karş. Dölle, Familienrecht, § 103 I, S. 397 vd.

63 Odersky, Nichtehelichengesetz, 627 vd. (Bielefeld 1971).

69 Karş. Dölle, Familienrecht, II, § 107 III, S. 472; Erman/Hefermehl, Ag. Kommentar, m. 1718, N 3; Soergel/Siebert/Lade, Ag. Kommentar, m. 1718. $\mathrm{N} 10$.

T Soergel/Hermann Lange, Ag. Kommentar, m. 1600 f, N 1; Palandt, Bür gerliches Gesetzbuch, m. 1600 f, N. 2 (München 1972). 
Baba tarafından yapılan beyanm niteliğine göre konuyu ikiye ayrarak incelemek mümkündür :

1. Bekâr baba tarafindan yapilan beyan babanın çocuğgu tanıdığını açıkça bildirmektedir : Bu takdirde Türk Vatandaşlık Kanunu m. 2'deki şart gerçekleșmiş olduğundan —eğer beyan șekline uygun olarak yapılmışsa- çocuk Tïrk tabiiyetini iktisap etmiştir. Alman devletler özel hukuku kuralı gereğince tanimada babanın hukuku olan Türk hukuku uygulanacaktır. Türk hukukunun atıf yaptığı çocuk hukuku da Türk hukuku olduğundan bu hukuka göre hareket edilecektir. Yani NEG m. 12'nin burada uygulanması muimkün değildir. Çünkü bu madde ancak Alman hukukunun uygulanacağı hallerde tatbik edilebilir.".$^{71}$ NEG m. 12 uygulanmadığı halde Türk hukukuna göre çocuk ile tabî̀ baba arasında hukukî ilişkỉer doğar.

2. Baba tarafindan yapılan beyanda çocuğun tanındığı ifade edilmemiştir : Bu takdirde çocuk Türk vatandaşlığnn iktisap etmez. Alman devletler özel hukuku bu konuda babanın hukukuna bakmaktadur. Babanm hukuku olan Türk hukukunda ise üstün görüș çocuğun hukukunun uygulanmasına taraftardır. \$u halde Türk devletler özel hukukunun yapmış olduğu atıf nedeniyle olaya Alman hukuku uygulanır. Yani NEG m. 12 burada geçerlidir ve geçerli olduğu için de baba tarafından yapılan beyan statï sonuçlarmı da doğuracaktır. Diğer bir deyişle, Türk erkek hiç istememiş olsa bile çocuk ile baba arasında örneğin akrabalık ve miras ilişsileri doğacaktır. Türk erkek çocuğun siciline baba olarak kaydolunabilecek. tir. ${ }^{\text {ta }}$

\section{Anamn Tirk Tabilyetinde Olmasi :}

Buraya kadarki izahatımızda kadının Alman olduğu hal incelenmiştir. Türk erkeklerinin Almanya'da Türk kadınlarla olan ilişki-

${ }^{71}$ Henrich, 8/9, Braasch, 188. Karș. Siehr, Internationalprivatrechtliches in der jüngsten Aenderung der Dienstanweisung für die Standesbeamten, StAZ, 104 vd (1972).

11a Ayni yönde, KG (Berlin Mahkemesi), 17.9.1971 tarihli karar. Olayda Türk erkek 27.4.1970 tarihli noter senedinde Alman kadından doğan çocựa 7.2.1969'dan 6.2.1987 ye kadar her ay 117 DM ödemeyi kabul etmişti. Kiși halleri memuru, ortada Türk hukukuna göre geçerli bir tantma bulunmadığından Türk erkeği nüfus siciline kaydetmek istemedi. Halbuki üst mahkeme, tanıma Alman hukukuna uyduğundan erkeğin baba olarak sicile tesciline karar verdi (StAZ 200 (1972), Der Amtsvormund 56 (1972)). 
lerinden de evlilik dışında çocuklar doğmaktadır. Bu gibi durumlarda Alman devletler özel hukuku erkeğin hukuku olan Türk hukukunun uygulanmasını istemektedir. Türk hukukundaki üstün görüş gerçi çocuğun hukukuna taraftardır, fakat çocuk da anası dolayısiyle, Türk Vatandașl1k Kanunu m. 1'e göre Türk tabiiyetinde oldugundan, uygulanacak hukuk gene Türk hukukudur. Ancak nafaka konusunda çocuğun mutad meskeninin bulunduğu yer hukuku uygulanir. ${ }^{72}$

\section{E. Ananın Yabanci Olmasi :}

Böyle bir durumda Alman hukuku babanın hukukunu, babanın hukuku olan Türk hukuku ise çocuğun hukukunu uygulamaktadır. Yapılan atıf nedeniyle Alman mahkemesi çocuğun hukukunu uygulamak durumundadır. Çocuğun hukuku ananın sahip olduğu tabiiyete göre değișecektir. Örneğin ana Yunan tabiîyetinde ise Yunan hukuku uygulanacaktır.

\section{TÜRK BABA TARAFINDAN TURKIYE'DE YAPILAN TA. NIMALAR :}

1. Türk devletler özel hukukunda tanımaya çocuğun hukuku uygulanacağından çocuğun tabiiyetine bakmak gerekecektir.

Ana Alman tabiiyetinde olduğundan çocuk da Alman tabiiyetindedir. Bu nedenle de tanımada Alman hukukuna bakmak gerekir. Alman hukukunda bu konuda iki görüșün bulunduğunu, son Medeni Kanun tadilinden sonra müelliflerin ana hukuku yerine baba hukukuna taraftar olduklarını yukarıda belirtmiștik. Türk hukukunda genellikle atıf kabul edildiğinden ${ }^{73}$ Alman devletler özel hukukundaki baba hukuku kuralı nedeni ile Türk baba tarafından Türkiyedeki tanımaya, ana Alman olsa dahi, Türk hukukunun uygulanması gerektiği sonucuna varılır.

2. Çocuk ve babanın Türkiye'de olması halinde eğer çocuk ve. ya babadan biri Türk ise Göğer Türk hukukunun uygulanmasını önermektedir. ${ }^{74}$ Bu takdirde ana ve ona bağhı olarak çocuk, Alman

\footnotetext{
${ }^{72}$ Bak. Yuk. IV. A 2 b) (5).

${ }^{73}$ Berki, 34 vd.; Göğer, 72; Uluocak, 212.

${ }^{24}$ Age., S. 215.
} 
tabiiyetinde olsalar bile Türkiyedeki tanımanın Türk hukukuna uygun bir şekilde yapılması gerekir.

3. Tanıma ile birlikte çocuk Türk vatandaşlı̆̆ını kazandığından (Vat. K. m. 2) tanımanın sonuçlarına Türk hukuku uygulanır.

VI. BABANIN ALMAN, ANANIN TÜRK VATANDAŞI OLMASI :

\section{A. Almanyadaki Tanımalar :}

Alman hukuku tanımaya babanın hukukunu uygulayacaktır. Yani baba Alman ise tanıma Alman hukukuna göre yaplmak gerekir. Halbuki Türk hukukunda üstün görüș bu konuda çocuğun -yani anaya bağlı olarak - Türk hukukunun uygulanması yönündedir. Alman hukuku tanımada Türk hukukunun aradığından daha fazla şartlar aradiğından Almanyada geçerli olan tanımanın Türk hukukuna da uygun olduğu söylenebilir.

Çocuk ile ana arasındaki ilişkiler bakımından Alman hukuku Türk hukukunun uygulanmasını öngörmektedir. Bu Türk devletler özel hukuku anlayıșına da uygundur.

\section{B. Tükiyede Yapılan Tanimalar :}

Türk devletler özel hukuku çocuğun hukukuna taraftar oldugundan ve anasına bağlı olarak çocuk Türk tabiiyetini kazandığından tanımaya Türk hukuku uygulanacaktır. Tanımanın sonuçları da hep Türk hukukuna tabidir.

\section{TANIMANIN \$̧EKLI :}

Tanımanın șekli bakımından Evlilik Dıșı Çocukların Tanımaların Kabule Yetkili Makamların Yetkilerinin Genişletilmesi Hakkındaki 1961 tarihli Roma Sözleşmesi her iki ülkede de uygulanacaktır: Bu sözleșmeye göre Türk ve Alman yetkilileri önünde yapılan tanıma beyanları iki ülkede de geçerlidir ${ }^{75}$ (m. 4). Alman hukukunda tanıma beyanı noterlikde, mahkemede, şahsi haller memurluğunda ve Jugendamt'larda yaptlabilir. ${ }^{76}$ Türk hukukunda noter senedi veya ölüme bağlı bir tasarrufla tanımanın yaplabileceğini daha önce belirtmiştik. Ayrıca yabancı ülkedeki Türk konsolosluklarnnda

75 Bak. Ilse - Dore Niclas, Beurkundung der Vaterschafts - und Mutterschaftsanerkenntnisse von Auslaendern im Jugendamt, 55 Zentralblatt f, Jugendrecht. u. Jugendwohlfahrt, 8 (1968).

76 Beitzke, 161. 
da Türkler tarafından tanımanın yapılip yapılamıyacağı tartışlabilir. Ȩ̇er tanınacak çocuk Türk tabiiyetinde ise tanımanın konsoloslukta beyan edilebilmesi mümkün olabilmelidir. ${ }^{n}$ Çünkü konsoloslar noterlerin görevlerini yabancı ülkede ifa ederler. Mamafih Almanya ile Türkiye arasında imzalanmıs olan Konsolosluk Anlaşması bu konuda bir açıklığa sahip değildir. ${ }^{78}$

\section{KAZAİ SALÂHIYET :}

\section{A. Genel Olarak :}

Tanımada yetkili mahkeme konusu kural olarak ortaya çıkmaz. Çünkü tanıma bir irade beyanı ile gerçekleşmektedir; ayrıca mahkeme kararı aranmaz. Bu beyanı her hangi bir kimse yapabileceği için, yani beyan sırasında biyolojik bağlantı araştırılmadı̆̆ndan, tanıyan kimsenin gerçek baba olmaması mümkündür. Böyle bir halde gerek Alman hukukunda ve gerekse Türk hukukunda bazı şahıslara tanımanın ref'i (iptali) davası açmak imkânı sağlanmıştır.

\section{B. Alman Hukuku :}

Alman Usul Kanununda yapılan değişiklik ile tanımanın iptal veya tespit davası ile ortadan kaldırılması yollanı açılmıștır. ${ }^{79}(\mathrm{~m}$. 640 II Nr. 3 ve Nr. 1). Tanıyan baba, ana ve çocuk, iptal davası açabilirler. ${ }^{\$ 0}$ Eğer taraflardan birisi, yahut sadece anne Alman tabiiyetinde ise Alman mahkemeleri böyle bir davayı görmeğe yetkilidir. ler. Ayrica davacı veya davalıdan birinin ikametgâhının Almanyada olması halinde de Alman mahkemelerinin yetkili olduğu kabul edilmektedir ${ }^{81}$ (ZPO 640 a). Tespit davasını ise ilgili üçüncü kișiler açabilecektir (ZPO 640 II Nr. 1, BGB m. 1600 b-1600 e). Bu ikinci davanın Alman mahkemelerinde göriilebilmesi de yukaridaki şartlara bağlıdır. Mamafih sadece ananın Alman tabiiyetinde olması Alman mahkemelerini yetkili krlmaz. ${ }^{20}$

${ }^{n}$ MK m. 291 II. Îsv. M. K. m. 303 tanyan kimsenin demektedir. Türk yazar. larından bunu tanıyan kimsenin mukayyet bulunduğu nüfus memuru șek. linde anlayanlar vardır. Velidedeoğlu, 411. Bak. Akantürk, 314. Bu bildirmeyi, haberdar oldukları takdirde konsolosluklar yapmaktadırlar. Tanıyan kimsenin veya tanınan çocuğun da yapması mümkündür. Velidedeo 1u, 411.

${ }^{78}$ Alman konsoloslarinın yetkisi hakkında bak. Alman Konsolosluk K. m. $16,17,37$ (8.11.1867 t. li, BGBl. S. 137). Odersky, 625.

${ }^{79}$ Siehr, 71.

$\$$ Beltzke, 162 vd.

${ }^{81}$ Siehr, 72; Soergel/Kegel, m. 18, N 30.

s Slehr, 74 . 


\section{c. Türk Hukuku :}

Türk hukukunda yetkili mahkeme konusunda tereddüde düşmek mümkündür. Bunun nedeni Medeni Kanunun ilgili 293 üncü maddesinin Isviçreden çevirisinde yapılan hatadır. Türk Medeni Kanununda, Isviçreden farklı olarak itirazın hakime yapılacağı ifade edilmiş, fakat itirazın ilgililere ahkâmı şahsiye memuru tarafından bildirileceği kaydı muhafaza edilmiștir. Diğer taraftan ahkamı sahsiye memurunun bulunduğu yer mahkemesinin yetkili oldu. ğu ifade edildiği halde bunun hangi ahkâmı şahsiye memurunun bulunduğu yer olduğu açıklanmamıştır. Aynı boșluk Isviçrede tanıyanın bağlı olduğu Kanton (Heimatort) şeklinde doldurulmuştur. Eğer tanıyan yabancı ise yetkili mahkeme çocuğun Isviçredeki Heimatort'udur. ${ }^{\$ 4}$ Türk hukukunda bunu tanıan kimsenin nüfusa kayıtlı bulunduğu yer mahkemesi șeklinde anlayan müellifler vardir ${ }^{85}$ Bu suretle m. 293 ve 294 ile m. 300 arasında bir ahenk sağlanabilmektedir.

MK m. 293 ile HYUK m. 18 arasındaki ilişki hakkında Türk hukukunda tartışmaya rastlayamadık. Fakat MK m. 300'ün HYUK m. 18 'deki kuralı değiştirip değiștirmediği tartıșma konusu yapılmıştır. Ứstün görüș burada HYUK m. 18'in değil MK. m. 300'ïn uygulanması șeklindedir. ${ }^{86}$ MK m. 293 bakımından da aynı görüşs savu. nulabilir. Yani Türkiyede ikametgâhı bulunmayan Türk tebaası ba. kımından yetkili mahkeme onun sakin olduğu yer, son ikametgâh veya Ankara mahkemesi değil, tanıyanın Türkiyede nüfusa kayıtlı olduğu yer mahkemesidir.

\section{Yabancı İlâmlarñ Tenfizi :}

Almanya ile Türkiye arasında yabancı ilâmların tenfizi hakkında bir Anlaşma bulunmadığından Alman mahkemelerince verilen kararların Türkiyede tanınması ve tenfizinin mümkün olmadığı savunulmaktadır. ${ }^{87}$ Ĕger bu görüş mutlak olarak kabul edilirse bir Türk erkeğin çocuğunu Almanyada tanıyabilmesi, fakat bununla ilgili itiraz davalarının Türkiyede görülmesi gerekecektir.

${ }^{83} \mathrm{Bu}$ görüş̧te, Velidedeoğlu, 411. Karş. Akmtïrk, 314.

${ }^{84}$ Hegnauer, m. 305, N 24, 38 vd. Karş. Isv. MK m. 313.

${ }^{85}$ Velidedeoglu, 418; Akantiork, 318.

${ }^{36}$ Tartışma için bak. O. Berki, 200/201 ve orada yapılan göndermeler.

87 O. Berki, 223. Fiili karşılıklı oluş hakkında bak. T. Ansay, Yabancı tlâmla rin Tenfizinde Karş̣lıklı Muamele Şart, 245 vd. (\$. \$.. Ansay'a Armağan. Ankara 1964). 